\title{
THE FORM OF NEW UNIVERSITIES IN BRITAIN
}

T HE second session of the Conference of Universities of the United Kingdom, held in London on December 10, discussed the problem of "Now Universities".

In the first half of the present century the growth of the number of university students has been comparatively slow in Britain, and the creation of new university institutions has depended largely on local initiative and finance. The university colleges have had to depend mainly on students from their immediate region, and their academic staff have had to work to the curricula and examinations of their parent, the University of London.

In the past few years the situation has been radically transformed; the establishment of the University College of North Staffordshire, with frankly experimental ideas, set the tone, and considerations of national prestige, the popular demand arising from new prosperity, and the demands of industry and defence have all contributed to a change whereby new institutions can be established with almost 100 per cent State aid for buildings, equipment and salaries, and institutions which will be free to plan and control their own courses and which will be free to experiment as boldly as they wish. These institutions are receiving abounding goodwill and assistance, from the University Grants Committee, local authorities, industry, other cultural institutions, the general public and the staffs of existing universities through the Association of University Teachers.

The two main addresses of the conference had a contrasting form, that of Mr. J. S. Fulton, principal of the University College of Sussex, dealing with the solutions of the problems of siting, staffing, curricula and policy as they were being worked out in practice and planning, and that of Prof. L. C. Sykes, of the University of Leicester, who spoke of the underlying principles which should guide a new university.

Mr. Fulton presented three main topics for discussion, namely, siting, size and function. The first topic appeared to offer two solutions, apart from considerations of population distribution : either the new university should be placed in some town like York, where there are already many othor cultural institutions, or in some area with few in the hope that it would become tho focus of cultural growth. Size would depend on two considerations : a minimum number of teachers to cover essential subjects would be 300 , with a staff-student ratio of 1 to 10 ; this would give a minimum student body of 3,000 . The maximum number would depend on the extent to which teaching methods and residential provision would offset the social disadvantages of larger numbers. Mr. Fulton thought that new institutions should grow rapidly, and he hoped that Sussex would reach 3,000 in ten years.

Mr. Fulton said that the growth of the student population and the new careers open to graduates require a new approach to teaching; he asked if courses devoted primarily to the development of scholars are necessarily appropriate to the 'new student'. At Sussex they are planning courses on lines which owe something to the experience of North Staffordshire. The courses in science have yet to be planned in detail, but in arts they are proposing a combination of an introductory first-year course with an intensive study of a subject in, not a department, but a 'school'. At first there are to be schools of European studies, English studies and social studies, to be followed with a school of international studies. In science, they are considering following the Cambridge pattern, with two main subjects examined at the end of three years, with subjects like the history or philosophy of science, with a further year in one subject for specialists. He hoped to see the development of courses that would link the faculties, biology with psychology or sociology with applied science.

Finally, Mr. Fulton said that he considered teaching should be based on some kind of tutorial system, which creates a close personal relationship between the teacher and the student.

There was much agreement in principle in the second address, by Prof. Sykes; but he also raised matters which provided much of the framework for the discussion which followed.

Education as a preparation for life rather than primarily as a professional training should be the aim of a new university, and to achieve this the university should devote energy to preparing the student's mind to use his course before he left school. This should be done through parents and teachers, as well as by means of mass media.

The problems of teaching for the citizens of the 'Affluent Society', who need more to control technology than to develop it, would depend on the attitude of mind of teachers. Teaching must no longer take second place in the interest of the academic staff, and research must no longer be the main criterion of academic worth. Successful teaching would depend in part on the creation of a community of learning in which domestic, architectural and landscape planning would be important, and in part on the development of a close personal relationship betwoon the student and the teacher through forms of tutorial teaching. In the discussion that followed, these points were taken up by the Archbishop of York, Dr. Ramsay, who saw the aim of new universities as being the promotion of new knowledge as the prerequisite of the training of the imagination and the creation of a wholeness of understanding.

The question of the priority of teaching over research was a matter about which the conference disagreed, and both Prof. W. F. K. Wynne-Jones, of Durham, and Prof. P. J. Hilton, of Birmingham, argued that successful teaching depends on research, and that the two are not necessarily competing but complementary.

Another topic raised by Prof. Sykes which was widely discussed was that of the full participation of all the acadernic staff in the governing of the institution. $\mathrm{He}_{\Theta}$ stated that if policy affects all, all should participate in its creation and that full information is the basis of loyalty. 
This point was taken up in discussion by Prof. J. M. Cameron, of Leeds, who spoke of the importance of popular sovereignty and the dangers of oligarchy. Mr. T. G. Miller, of North Staffordshire, and Mr. H. Maddick, of the Association of University Teachers, supported these arguments, and the former urged the ending of the distinction between 'professorial' and 'non-professorial' teachers.

The problem of the independence of the new institution was raised by Prof. Sykes, and he emphasized the need for local financial and other support. In this he was supported with evidence by Prof. A. K. Stout, of Sydney, and Prof. J. E. Corry, the vice-principal of Queen's University, Ontario, both of whom dealt with some of the problems of political control. A reassurance was offered on this matter by Viscount Mackintosh of Halifax, who described the wide range of support given to Norwich by the University Grants Committee, by the general public, and by industry, commerce and the arts in the counties of Norfolk and Suffolk.

In contrast to the ideas of Mr. Fulton and in support of the thesis of Prof. Sykes, Prof. W. A. C. Stewart, of the University College of North Staffordshire, suggested that slow growth might in fact be the prerequisite of the development of successful interdiseiplinary courses, and he pointed out that his institution now has 800 students after ten years growth.

The sense of the conference was--it had no formal resolutions or conclusions - that education in the 'new universities' should be liberal rather than technical in the narrow sense, and should educate the whole man, or woman, for life rather than for a career.

\section{IMPACT OF MAN ON THE VEGETATION OF THE HUMID TROPICS}

$\mathrm{A}^{\mathrm{N}}$ $\mathrm{N}$ enterprising and successful symposium, convened by the Unesco South East Asia Science Co-operation Office, was held at Goroka, New Guinea, during September. It was brought to fruition through the generous hospitality of the Administration of Papua and the Territory of New Guinea and the unremitting efforts of J. S. Womersley, ehief of the Division of Botany, Department of Forests, Lae. Thirty delegates attended from Australia, India, Indonesia, Malaya, Philippines, Sarawak, Singapore, Thailand, Great Britain, the United States, the Territory of Papua and New Guinea, and the South Pacific Commission. There were also twelve observers from the Territory, among whom Mr. H. P. Seale, district commissioner of the Eastern Highlands, was elected president of the symposium. Delegates arrived at Port Moresby, and on September 14 they were taken by charter-plane across the high mountains to Goroka at an altitude of 5,000 ft. Any doubts about the suitability of the site were soon dispelled by the comfort of the Goroka Hotel and the warm welcome from the district commissioner. In these inspiring surroundings, old in their display of the effects of early man in the valleys and on the mountain-sides, befitting the topic of the symposium, and new in the post-war growth of the administrative centre, a vigorous speech from the assistant administrator, Dr. J. T. Gunther, on behalf of the administrator, Brigadier D. M. Cleland, inaugurated the symposium. It was time, he said, to end not only the wars of man on man, but of man on beasts, and of man on vegetation. He struck a theme which forced itself into the chief recommendation of the meeting. The grandeur of Nature, the poverty of man, and the ideal of human rights surged into the panorama, for the object of the symposium was to bring together agriculturists, botanists, foresters, administrators, anthropologists and geographers in South East Asia and tropical Oceania.

Thirty-six papers had been presented and duplicated for previous study, and an efficient secretariat, brought from Port Moresby, reported the discussions in full. First, the physical and human backgrounds of the humid tropics were considered. Illness prevented
Prof. W. A. R. Wikramateleke (Singapore) from giving the opening discourse, and in his place the aspects of climatology were presented by Prof. J. M. Blaut (Yale University), of soils and substrata by Dr. F. R. Fosberg (National Research Council, Washington), and of vegetation by myself. Prof. W. R. Geddes (University of Sydney) followed with a sympathetic approach to the human background, based particularly on his researches in Indo-China and Sarawak; he emphasized the ' $c$ ' in Unesco as the all-important socio-cultural element of human community and, indeed, the mark of man. The second topic, on the selection and cultivation of foods by early man, was introduced by Dr. J. Barrau (South Pacific Commission). He explained how early man was a practical geneticist selecting by taboo which prevented misappropriation and loss of valuable plants, thereby preserving the better yielders in the multitude of wild variety; the procedure was in striking contrast with the tendency to exterminate the valuable beasts. He was directing his studies to the problem of the bread-fruit tree, so widely cultivated in great variety, yet so obviously wild in New Guinea and the Melanesian islands. This important plant, too massive for interpretation in the herbarium, had to be studied in the arboretum, on which task he was bent. The problem of the sweet potato, chased by the peoples of New Guinea from valley to valley in almost maniacal destruction of the forest, raised considerable doubt on its supposed American origin. Fosberg presented his ideas on the origin of the coco-nut as a cultigen, the ancestral form of which botanists had not yet adequately contemplated. $\mathrm{Mr}$. G. P. Keleny (Port Moresby) gave a detailed account of the basic food-crops of New Guinea. Dr. M. J. Meggitt (University of Sydney) explained his work on the native agricultural methods of the Western Highlands, showing the readiness with which new food-crops may be taken up. Mr. W. L. Conroy (Department of Agriculture, New Guinea), in comparing the effects of indigenous agriculture on soilerosion and soil-deterioration with those of land-slides in forested country, considered that the damage supposed to be caused by deforestation might well be 